\title{
RAINWATER HARVESTING SYSTEM: LOW AWARENESS LEVEL AMONG UNIVERSITY STUDENTS IN A HIGH RAINFALL TROPICAL COUNTRY
}

\author{
Pey Fang Tan' ${ }^{1}$, Marlia M. Hanafiah ${ }^{1,}{ }^{*}$, Mazlin B. Mokhtar ${ }^{2}$, Siti Norliyana Harun ${ }^{1}$ \\ ${ }^{1}$ School of Environmental and Natural Resource Sciences, Faculty of Science and Technology, Universiti \\ Kebangsaan Malaysia, 43600 UKM Bangi, Selangor, Malaysia. \\ ${ }^{2}$ LESTARI, Universiti Kebangsaan Malaysia, 43600 UKM Bangi, Selangor, Malaysia. \\ *Corresponding author E-mail address: mhmarlia@ukm.edu.my
}

This is an open access article distributed under the Creative Commons Attribution License, which permits unrestricted use, distribution, and reproduction in any medium, provided the original work is properly cited

\section{ARTICLE DETAILS}

Article history:

Received 12 September 2017

Accepted 19 October 2017

Available online 30 October 2017

\section{Keywords:}

Rainwater harvesting system; awareness level; water quality; sustainable water resource; Malaysia

\begin{abstract}
Water scarcity has emerged as a global issue and the situation is getting worse. In accordance with the urgency, this study aimed to assess the suitability of a rainwater harvesting system (RWHS) to supply water for domestic uses in residential colleges in the Bangi campus of Universiti Kebangsaan Malaysia (UKM). The study also analysed the level of awareness on the importance of rainwater and RWHS among the students residing in the 10 residential colleges. The study used Likert scale $1-5$ questionnaire survey method and the sample involved 1,075 respondents randomly selected from 10 residential colleges in UKM. The findings showed that the suitability of rainwater collected by the RWHS for domestic uses had a mean of 3.45, while the mean value of awareness level towards the importance of rainwater and RWHS was 3.75. The questions group with the lowest mean score was "knowledge regarding the objectives of collection and reuse of rainwater", with a mean of 3.28. A case study of RWHS was carried out by installing a RWHS in one of the residential college, namely Ungku Omar College. Residents at Ungku Omar College got the highest total percentage for "agree" and "strongly agree" scores when being asked if rainwater collected by RWHS is suitable for domestic uses, as compared to the scores obtained by other residential colleges. Among the important aspects of RWHS include safety of water collected, sustainability of the system and quantity of water collected with mean of 4.39, 4.19 and 4.07, respectively. In conclusion, RWHS is a method that can be widely accepted among college students at UKM, mainly for domestic uses. However, further efforts should be incorporated to increase the awareness level and knowledge on the importance of conserving water resource.
\end{abstract}

\section{INTRODUCTION}

Malaysia is a tropical country that received an average amount of rainwater distribution of 1151 - $5687 \mathrm{~mm}$ per year. However, if it is not fully utilized, it is feared Malaysia will face an acute water crisis due to rapid population increase, water pollution and water resources depletion during dry season. The water crisis is predicted to be more acute in near decades if the population growth is keep rising [1]. The volume of rainwater which is high in Malaysia allows the exploration of alternative sources of water supply using a rainwater harvesting system (RWHS). Rainwater harvesting for domestic uses have been identified in terms of its importance as an alternative water source, especially during water shortages. Various aspects involved including weather, characteristics of the building, effectiveness of the tank size, economy and ecology are crucial to ensure the success of RWHS. Rainwater harvesting for domestic uses have been carried out in Taiwan, where the problem of water supply is one of the major issues. Although Taiwan received a total rainfall of $2457 \mathrm{~mm}$ per year, which is 2.6 times the average for that obtained by other countries of the world, but only $4074 \mathrm{~m} 3$ per capita per year of rainwater can be used. Construction of dam can be done but high erosion causing sedimentation contributes to siltation of dams. Groundwater extraction cannot be done excessively because of the fear of underground movement contributes to the collapse of land mainly in the coastal region [2]. Therefore, green building policy has been introduced by suggesting that all buildings with a floor area of more than 10,000 $\mathrm{m} 2$ are required to install RWHS [3].

This research was conducted to assess the level of awareness among the students on the importance of water resources and RWHS in 10 residential colleges in the Bangi campus of UKM. This paper also reviewed the suitability of RWHS to supply water for domestic uses in residential colleges of the Bangi campus of UKM. The results obtained could be used to determine the effectiveness of the system and this can be used to forecast its application in other buildings.

\section{METHODOLOGY}

This research was based on a literature review and distribution of questionnaire survey to 10 residential colleges of the Bangi campus of Universiti Kebangsaan Malaysia (UKM), located in Selangor. Data obtained from questionnaires was developed using Likert scale of the interval and ordinal types. For questions with Likert scale interval type, the appropriate type of analysis is the mean, median, mode and standard deviation. The level of awareness towards the issue of water supply are categorized according to the composite score of such questions. Respondents who answered a score of 1, 2, 3, 4 and 5 have a low, moderate, neutral, good and high level of awareness, respectively. Likert scale questionnaire was chosen because it suitable for surveying the level of awareness regarding environmental issues [4]. Measurement in Likert scale was used for each statement of water supply crisis and each item was given a scale of 1 to 5 , namely:

\section{$1=$ Strongly disagree \\ $2=$ Disagree \\ $3=$ Unsure $/$ neutral \\ $4=$ Agree \\ 5 = Strongly agree}

The data was inserted into the computer software namely Statistical Package for the Social Sciences (SPSS) version 22, which was developed by IBM. Mean for each group of questions was investigated to determine whether the level of awareness among students is high or low. Analysis was done to determine the demographic factors. One of the 10 residential colleges, namely Kolej Ungku Omar (KUO) was selected as the case study area. Since February 2015, KUO has been facing very serious water supply problem. According to the UKM Infrastructure Unit, KUO was in a zone where water supply comes from Semenyih Water Treatment Plant which caters to many densely populated areas. Some part of the UKM Bangi campus facing less water supply problems because the source of water was from the Langat Water Treatment Plant.

\section{RESULTS AND DISCUSSION}

In this study, the sample size was 1,075 respondents, following the sample size proposed by a researcher. For students in residential colleges, the suitability of collecting rainwater with the RWHS method for supplying water for domestic uses has a mean of 3.45 , with a standard deviation of 0.801 .

As shown in Table 1, among the 10 groups of questions asked, the group question that has the lowest score is the mean for the group S8 (Knowledge related to objectives of the collection and reuse of rainwater) which was only 3.28 (standard deviation of 0.775 ). These statistics show that the knowledge of students in the residential colleges related to the objectives of collecting and re-use of rainwater is very low compared with the other questions developed in the questionnaire survey. 
Table 1: Mean for 10 main groups of questions

\begin{tabular}{|llll|}
\hline No. & Question group & Mean & $\begin{array}{l}\text { Standard } \\
\text { deviation }\end{array}$ \\
\hline 1 & $\begin{array}{l}\text { S2 (Resource conservation measures / } \\
\text { reduction of environmental pollution) }\end{array}$ & 4.30 & 0.503 \\
3 & $\begin{array}{l}\text { S5 (Steps have been taken in the residential } \\
\text { colleges to avoid wasting water) }\end{array}$ & 4.25 & 0.615 \\
4 & $\begin{array}{l}\text { S6 (Water conservation efforts) } \\
\text { S10 (Aspect preferred in the RWHS } \\
\text { application for water supply in residential } \\
\text { colleges) }\end{array}$ & 4.16 & 0.647 \\
5 & $\begin{array}{l}\text { S9 (Why do you support the installation of } \\
\text { RWHS in residential college?) }\end{array}$ & 4.13 & 0.602 \\
7 & $\begin{array}{l}\text { S4 (Should water saving measures practiced } \\
\text { at home, same as those listed in S3, can also } \\
\text { be practiced in a residential college?) }\end{array}$ & 3.96 & 0.718 \\
8 & $\begin{array}{l}\text { S3 (Steps have been taken to reduce water } \\
\text { consumption at home) }\end{array}$ & 3.91 & 0.728 \\
9 & $\begin{array}{l}\text { S1 (Sensitivity to environmental issues) } \\
\text { S7 (The level of understanding regarding } \\
\text { RWHS) }\end{array}$ & 3.54 & 0.676 \\
10 & $\begin{array}{l}\text { S8 (Knowledge of the objectives of } \\
\text { collecting and re-use of rainwater) }\end{array}$ & 3.34 & 0.696 \\
\hline
\end{tabular}

Questions group S2 (Steps of resources conservation / reduction of environmental pollution) was a collection of question that has the highest mean score of 4.30 (standard deviation of 0.503). Knowledge associated with measures of reduction of environmental pollution has long existed among the population of Malaysia. However, in this context the implementation of the measures is much more crucial.

Compared to other groups of questions, the lowest mean score was found for the question related to collection and re-use of rainwater. According to a research, most of the rainwater harvested with RWHS can only be used for the supply of daily domestic activities such as gardening, washing vehicles and cleaning [5]. Perceptions of the respondents regarding whether the rainwater collected by RWHS is fit for drinking is minimal (min 2.59, standard deviation 1.183, median 3.00). For the bathroom uses, the respondents' confidence rose slightly to 2.94 in mean (standard deviation of 1.162 , median 3.00). For the use of washing clothes, the mean was 3:59 min (0.959 standard deviation, median 4.00). In various uses of the rainwater collected as proposed in the questionnaire, the highest mean is for washing the toilets, with a mean of 3.84 (standard deviation of 0.920 , median 4.00 ).

However, the mean for all questions related to the use of rainwater collected with RWHS were found to be less than 4 .

Some of research paper stated that in contrast to the believe that water collected from the roof is safe, the data showed chemical-physical aspects of pollution and microbiology, leaching and erosion of roof materials, storage facilities or channelling, and faecal contamination could affect the quality of the rainwater harvested [6]. Epidemiological studies linking the use of rainwater with the public health risk is limited, especially in developing countries. The findings also showed that the perception of college students in KUO towards the suitability of using RWHS for domestic purposes was higher as compared to all 10 residential colleges in the campus. The total percentages of "agree" and "strongly agree" among residents were $46.5 \%$ and $41.4 \%$, respectively as shown in Figure 1.

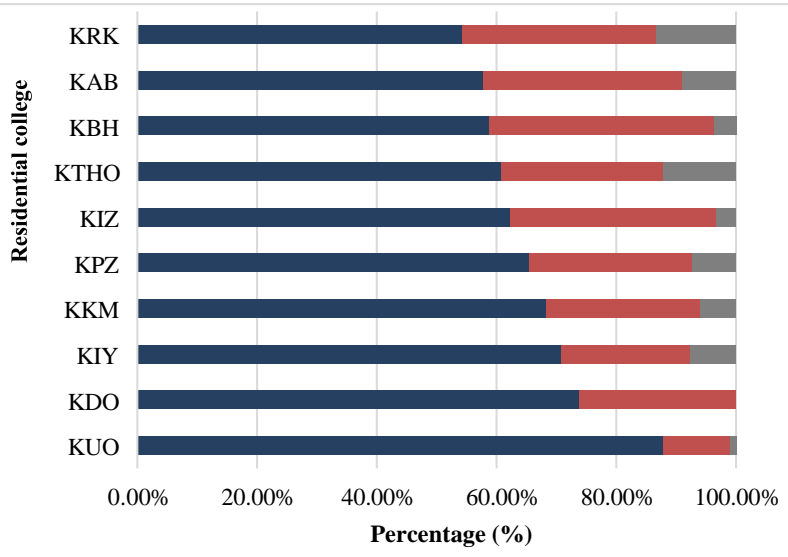

- Strongly Agree and Agree • Unsure / Neutral Disagree and Strongly Disagree
Figure 1: Comparison between the percentage of respondents in each residential college for question S8 (Rainwater was collected for domestic uses)

RWHS may also contribute to saving money or profit generation. SubSaharan in Africa is facing the effects of climate change, increasing farmers' income and secure food supplies were done by collecting rainwater in-situ [7]. RWHS is not only for supplying water to the area prone to water shortage and lack of rain, but the use of RWHS can delaying storm water runoff into water bodies.

Table 2: Statistics for questions group S10 (Practices related to the application of RWHS for water supply in residential colleges)

\begin{tabular}{|lllll|}
\hline No. & Question & Min & Median & $\begin{array}{l}\text { Standard } \\
\text { deviation }\end{array}$ \\
\hline 1 & $\begin{array}{l}\text { S10_46 I give priority to the safety of water } \\
\text { for water supply. }\end{array}$ & 4.39 & 5.00 & 0.726 \\
2 & $\begin{array}{l}\text { S10_45 I give priority to the quality of water } \\
\text { for water supply. }\end{array}$ & 4.38 & 5.00 & 0.761 \\
$3 \quad \begin{array}{l}\text { S10_50 I give priority to the sustainability of } \\
\text { RWHS. }\end{array}$ & 4.19 & 4.00 & 0.832 \\
$4 \quad \begin{array}{l}\text { S10_47 I give priority to the quantity of } \\
\text { water collected by the RWHS. }\end{array}$ & 4.07 & 4.00 & 0.822 \\
5 & $\begin{array}{l}\text { S10_49 I give priority to the suitability of } \\
\text { RWHS for uses in the residential college. }\end{array}$ & 4.03 & 4.00 & 0.829 \\
6 & $\begin{array}{l}\text { S10_48 I give priority to the installation costs } \\
\text { of RWHS. }\end{array}$ & 3.87 & 4.00 & 0.914 \\
\hline
\end{tabular}

Table 2 above shows the mean, median and standard deviation of the S10 group of questions concerning priorities for the use of RWHS in residential colleges. The most preferred aspect of concern is the safety aspects of water (S10_46 I give priority to the safety of water for water supply) with a mean of 4.39 (median of 5.00 and standard deviation of 0.726 ). A research reported a total of 3840 RWHS was assessed at daily intervals and various aspects including cost for installation are important to be considered. The main cost of RWHS is related to the installation of the RWHS itself. Regarding the cost of installation, (S10_48 " I give priority to the installation costs of RWHS.), the government will introduce the concept of rainwater harvesting so that the cost of water treatment can be reduced [5].

\section{CONCLUSIONS}

This study has been successfully reviewing the opinion related to RWHS among the students who occupy the residential colleges in the Bangi campus of UKM, one of the leading research universities in Malaysia. The views and the level of awareness of the importance of water resources and RWHS among students that occupied residential colleges in the campus were analysed. In accordance with the urgency of the water crisis in recent years, the installation of RWHS as alternative for water supply for domestic uses in residential colleges of UKM needs to be encouraged.

The findings show that the level of agreement among students in the residential college regarding the importance of water resources and the suitability of water collected by RWHS for domestic uses has a mean of 3.45 (standard deviation 0.801) and awareness of the importance of rain as water resources and RWHS for supplying water for domestic uses were at the mean of 3.75 (with a standard deviation of 0.677). Among the 10 groups of questions asked in the questionnaire, the questions with lowest mean score was the group that refers to knowledge of objective of collection and reuse of rainwater, which has a mean of 3.28 (standard deviation of 0.775 ). In conclusion, rainwater harvesting is an initiative that can be accepted among students in the residential college mainly for domestic uses only. However, there is still room to improve knowledge or exposure at this early stage. It is recommended that the study on the safety of the water collected by RWHS in terms of microbiology should be continued. Knowledge on RWHS still need to be improved among students of UKM so that they are more confident in using the water collected from the rainfall in the future. Hopefully, RWHS will be practiced in order to achieve sustainable development of the country.

\section{ACKNOWLEDGEMENT}

Marlia Mohd Hanafiah was financed by research grants: FRGS/2/2013/ STWN01/UKM/03/1 and TD-2014-012.

\section{REFERENCES}

[1] Falkenmark, M. 1987. Water-related constraints to African development in the next few decades. Water for the Future: Hydrology in 
Perspective (Proceedings of the RomeSymposium, April 1987) IAHS Publ, $164,439$.

[2] Falkenmark, M. 1989. The Massive Water Scarcity Now Threatening Africa - WhyIsn't It Being Addressed? Royal Swedish Academy of Sciences, $18(2), 112$.

[3] Liaw, C.H., and Chiang, Y.C. 2014. Framework for Assessing the RainwaterHarvesting Potential of Residential Buildings at a National Level as an Alternative WaterResource for Domestic Water Supply in Taiwan. Water, 6 (10), 3224-3246.

[4] Asmawi, A. P. M. Z., and Ibrahim, A. N. 2011. The Level of Awareness TowardsEnvironmental Issues and Concern among Students in Tertiary Level. 11th InternationalCongress of Asian Planning Schools Association (APSA 2011),
19-21 September 2011.Tokyo: University of Tokyo Hongo Campus.

[5] Shamsuddin, M., Hashim, N.M., Ahmad, A.H., Khin, M.T., and Sidek, N.S. 2014.Kebolehupayaan sistem penuaian hujan sebagai bekalan air alternatif di Malaysia: Suatupenelitian awal. Geografia: Malaysian Journal of Society and Space, 10 (6), 97-104.

[6] Gwenzi, W., Dunjana, N., Pisa, C., Tauro, T., and Nyamadzawo, G. 2015. WaterQuality and Public Health Risks Associated with Roof Rainwater Harvesting Systemsfor Potable Supply: Review and Perspectives. Sustainability of Water Quality andEcology, 6, 107-118.

[7] Vohland, K., and Barry, B. 2009. A review of in situ rainwater harvesting (RWH)practices modifying landscape functions in African drylands. Agriculture, Ecosystems \&Environment, 131 (3-4), 119-127. 